\title{
SDG-Oriented Supply Chains: Business Practices for Procurement and Distribution
}

\author{
Antonello Cammarano ${ }^{1}{ }^{(}$, Mirko Perano ${ }^{2, *} \mathbb{C}$, Francesca Michelino ${ }^{1}$, Claudio Del Regno ${ }^{3}$ and Mauro Caputo ${ }^{1}$ \\ 1 Department of Industrial Engineering, University of Salerno, 84084 Fisciano, Italy; \\ acammarano@unisa.it (A.C.); fmichelino@unisa.it (F.M.); mcaputo@unisa.it (M.C.) \\ 2 Department of Management \& Innovation Systems, University of Salerno, 84084 Fisciano, Italy \\ 3 Department of Management, Reald University College, 9400 Vlorë, Albania; \\ claudio.delregno@unireald.edu.al \\ * Correspondence: mperano@unisa.it
}

check for updates

Citation: Cammarano, A.; Perano, M.; Michelino, F.; Del Regno, C.; Caputo, M. SDG-Oriented Supply Chains: Business Practices for Procurement and Distribution. Sustainability 2022, 14, 1325. https://doi.org/10.3390/su14031325

Academic Editor: Giada La Scalia

Received: 31 December 2021

Accepted: 21 January 2022

Published: 25 January 2022

Publisher's Note: MDPI stays neutral with regard to jurisdictional claims in published maps and institutional affiliations.

Copyright: (C) 2022 by the authors. Licensee MDPI, Basel, Switzerland. This article is an open access article distributed under the terms and conditions of the Creative Commons Attribution (CC BY) license (https:// creativecommons.org/licenses/by/ $4.0 /)$.

\begin{abstract}
This paper aims at analyzing sustainable practices that can be implemented within supply chains, linking them to Sustainable Development Goals (SDGs) in order to show the performance achieved by SDG-oriented supply chains. Sustainable practices were collected from the repository "Business Process Framework for Sustainability" owned by the Department of Industrial Engineering of the University of Salerno (Italy). By using literature research and descriptive statistics, there emerges a positive relationship between sustainable development and SC performance enhancement. From the study of the practices that can be implemented for cooperation activities with upstream and downstream supply chain partners, it emerges that companies have many opportunities of both supporting the 2030 Agenda and enhancing their market and organizational performance. The research demonstrates that both procurement and distribution processes could be reengineered by implementing sustainable approaches considering all three dimensions of sustainability. Differences emerge in terms of number of opportunities, depending on motivations for implementing them, industry and supply chain processes, performance achieved, and SDGs pursued.
\end{abstract}

Keywords: supply chain; Sustainable Development Goals (SDG); sustainability; distribution; procurement

\section{Introduction}

A supply chain is a complex service system [1]. The sustainability of actions for the future generation [2] can be used to explain supply chains. In this sense, a sustainable supply chain is a traditional supply chain (SC) that is oriented towards sustainable development, incorporating economic, environmental, and social dimensions of sustainability [3]. Sustainability is linked "to the needs to determine a balance between consumption -growthdevelopment" [4]. Under this lens, sustainability can be considered as a key for achieving a competitive advantage for all the members of the SC, improving profitability and performance [5]. This requires collaboration among manufacturer and downstream/upstream partners to improve environmental, social, and economic performance within SC operations. In the last decade, the number of scientific articles focusing on the relationship between sustainable development and SC management has been significantly growing. In particular, studies on green supply chains are predominant [6], whereas social sustainability in SCs has received less attention in the literature. Concepts such as sustainable development, sustainable innovation, and sustainable-driven innovation are more and more common among companies and within SCs and will assume a significant role in terms of competitive advantage, e.g., providing opportunities of cost savings and improvements in terms of market performance. Moreover, innovation stimulated by digital transformation can contribute to creating a competitive advantage oriented toward preserving environmental sustainability and collective wellbeing [7-10]. However, initiatives carried out by the 
private sector in terms of sustainable development should be in line with the expectations of the United Nations and policy makers. In particular, the 2030 Agenda defines a set of 17 Sustainable Development Goals (SDGs) and 169 targets, involving many actors such as citizens and private and public entities. Even though companies have a significant role in the achievement of such goals, the SDG framework does not specify "how" firms should refocus, reorganize, and reengineer their processes to support the 2030 Agenda. Since the achievement of SDGs requires a collective effort and cooperation among actors, SCs are particularly affected by such changes towards new and sustainable ways of doing business. From the literature review, the number of contributions focusing on the impact of the SCs on the achievement of the Sustainable Development Goals (SDGs) is still inadequate. Apart from scientific contributions providing an integrated holistic approach to face the issue, the literature presents studies on a limited number of companies or focuses on specific industries or few SDGs. Therefore, there is a need of summarizing these contributions in order to build a repository of sustainable practices that are formally linked to at least one SDG and that clarify "how" to both support the 2030 Agenda and obtain business performance improvements. Consequently, a first research gap that this work intends to fill is the direct linkage between SDGs and activities carried out within SCs. Even though the literature on sustainable SCs is rich in contributions, there are no comprehensive studies that look at SCs from the perspective of the achievement of SDGs, understanding their formal contribution to the 2030 Agenda. Indeed, as to the issue of sustainability, companies usually refer to the traditional triple bottom line concept, which is simpler to implement within companies' sustainability frameworks, but not exhaustive.

With this work, a quantitative analysis of the state of the art of sustainable practices is presented, employing data collected from the project "Business Process Framework for Sustainability" carried out by the Department of Industrial Engineering of the University of Salerno (Fisciano, Italy). Indeed, a repository of practices is analyzed in order to study the impact of SCs on the achievement of SDGs, considering relationships with both downstream and upstream SC partners, with a focus on procurement and distribution activities. Such a repository records a list of practices extracted from about 3000 scientific papers, which have been thoroughly analyzed by experts in the field of sustainable development and business management, while also defining for each practice a set of standardized labels associated with the industry of possible implementation, the SC processes that could enable carrying out of the sustainable practice, and the impact on the business in terms of either market or organizational performance. Moreover, each sustainable practice is also associated with at least one SDG. This will support the understanding of the different opportunities of implementation of SDG-oriented practices within both procurement and distribution processes, also depending on business- and sustainability-related issues. Therefore, it will be possible to enable the most frequent linkages with SDGs to emerge, and thereby to suggest which sustainability areas procurement and distribution activities could positively affect.

With all this presented, the aim of this paper is twofold: firstly, investigate the relationship between SCs and SDGs; secondly, portray the state of the art of current sustainable practices that could be implemented within SCs to support SDGs.

In order to achieve these goals, the paper is structured as follows. A literature review on the relationship between SCs and SDGs is presented, followed by a focus on procurement and distribution processes. Thereafter, a description of how the repository was built from the analysis of scientific papers is presented, with a discussion of the standardized labels assigned to each sustainable practice. Afterwards, the analysis of the repository is performed to show the role of SCs in supporting the achievement of SDGs and the business performance enhancement opportunities that could result at the same time. Finally, discussions and a conclusion close the work, with a focus on theoretical, methodological, managerial, and practical implications of the research. 


\section{Theoretical Background}

In this paper we use three different theoretical approaches to frame the phenomenon observed. The background starts from the supply chain; it includes procurement and concludes with distribution; all is related to the Sustainable Development Goals. Below are the specific sub-sections.

\subsection{Supply Chains and Sustainable Development Goals}

Firms and supply chains are fundamental for achieving the 2030 Agenda. Indeed, they manage human, natural, and financial resources, thus directly influencing sustainability issues [11-13]. By using a relational approach, firms and supply chains create a supply network that through the lens of the triple bottom line aims to "find a trade-off between economic, environmental and social dimensions, simultaneously" [14]. Since the literature underscores that future competition will be based on sustainability issues [15], companies should promote sustainability and address their investments towards new approaches in line with SDGs [16], while also including industry 4.0 technologies [17].

However, while the "policy maker" perspective is widely investigated, literature on the relationship between the private sector and the 2030 Agenda is still undersized $[18,19]$. Even though scholars have focused their attention on case studies and models of the implementation of sustainable development practices, a direct linkage to SDGs is infrequent. To date, the literature tends to focus on a simpler association between sustainable development and firms, in the form of concepts such as sustainability-oriented innovation [20]. Supply chains aim at maximizing profits, enhancing customer satisfaction, and optimizing SC costs; there is therefore an undeniable trade-off with SDGs [18]. The literature underscores that there is a need of clarifying "how" firms should manage such a trade-off [11,16]. However, SCs have been the locus for technological progress, being the main seed for innovation, technological development, and diffusion of knowledge [21-25]. Therefore, they could be ready to change, reengineer, and implement processes and activities from a sustainable perspective.

Moreover, scholars affirm that there is a need for frameworks to integrate SDGs within firms' strategies [26,27]. As to SC management, it is necessary to reorganize relationships with all SC partners, in which human, financial, and material resources are shared among members. An effective implementation of sustainable development within SC requires the concrete and formal engagements of all stakeholders and actors [28].

Therefore, from the literature review it emerges that research is more and more concentrating on sustainable development and sustainability-oriented innovation, but without any formal linkage to the 2030 Agenda. In order to investigate the relationship between SCs and SDGs and differently from the extant literature which provides a holistic discussion about the opportunities deriving from implementing strategies in line with SDGs $[11-13,16,18,19,26,27,29]$, this paper provides statistics about the direct relationship between SCs and SDGs. From these statistics, a clearer understanding of the state of the art of actual sustainable practices implementable within SCs to support SDGs is provided. This result represents an original point of view differentiated from other scientific contributions focused on either specific case studies/industries [30,31] or a limited number of SDGs [32].

The following sections provide a brief literature review on the main issues under investigation as to the procurement and distribution processes.

\subsection{Procurement and Sustainable Development Practices}

Since raw materials and components are purchased from suppliers, their activities affect SC sustainability $[3,33]$. Many researchers have focused on supplier selection, proposing sustainability criteria to assess sustainability levels [34] and mainly focusing on environmental issues associated with the concept of green sourcing and green SC [35-38]. Relatively few papers have considered social criteria [39]. The number of scientific articles suggesting frameworks and methodologies for supplier selection that enclose sustainability-related criteria is growing considerably $[34,40,41]$. 
A further element of analysis is the need of SC integration between suppliers and buyers to support sustainability, for instance by suggesting a "lean" philosophy [42], and circular economy approaches [43-45]. Moreover, scholars focus on the SC sustainability assessment, i.e., the process for analyzing the levels of sustainability, which is fundamental to control and monitor the impact of the SC on economic, environmental, and social issues [46].

The scientific literature is underscoring that sustainable SCs are able to achieve cost reduction and enhance product quality. Since on average about 70 percent of SC costs pertain to purchasing activities [47], sustainability can be also considered as a means for reengineering processes and achieving organizational performance improvements [48].

From the analysis of the literature, a direct relationship between procurement practices and SDGs is lacking. Indeed, the literature has underscored those relationships with suppliers have to be addressed towards environmental issues-such as waste, material usage, energy consumption, and emission reduction [42] —and social problems—such as poverty, social exclusion, corruption, human rights, safety, and equity [49]. However, even though sustainability is more and more becoming a key factor for buyer-supplier relationships in SC, a direct linkage with their contribution on SDGs is lacking, with only a few studies underscoring the direct linkage. Exceptions are studies on specific opportunities, such as the relationship between SDGs and the industrial sharing economy [50], as well as investigations of particular industries, such as the food SC which have found a relationship with SDGs 2, 12 and 13 [42], the petrochemical SC associated with SDGs 3, 6, 8, 9, 12 and 13 [34], and the textile SC linked to SDGs 8 and 12 [51].

\subsection{Distribution and Sustainable Development Practices}

Distribution and logistics enclose various resource-consuming processes such as transportation, delivery, and warehouse activities; relationships with 3PL, 4PL, carriers, distributors, wholesalers, and retailers; and inventory management and reverse logistics activities. Sustainable approaches could radically change such processes, and the literature is rich in contributions signaling the impact on the environment. For instance, scholars have investigated the implementation of eco-design strategies to improve packaging sustainability, including both their use and their disposal [52]. Moreover, there is a growing interest in reverse logistics activities, which are fundamental for supporting circular and green economies, closed-loop SCs, and sustainable and eco-friendly development [53-56]. Obviously, transportation processes have been widely investigated, due to their relevant impact in terms of greenhouse gas emissions. Research has focused on optimizing transportation processes, including planning, and suggesting new promising vehicle technologies [57,58]. Transportation research has also focused on the optimization of activities within sea terminals, e.g., considering sustainability-related parameters to optimize container terminal performance [59]. Warehouse efficiency could be enhanced by optimizing material handling and improving the space utilization of storage facilities [60]. Regarding supply network design, the literature suggests frameworks for selecting sustainable plant and warehouse locations [61]. New inventory management approaches have been suggested to reduce carbon emissions to protect against global warming, e.g., the sustainable economic order quantity model [62]. Moreover, the literature has discussed the role of outsourcing logistics services to 3PL and 4PL providers in terms of environmental sustainability [63].

Regardless of specific processes, some studies face the problem of optimizing sustainability of the entire set of distribution activities. For instance, optimization tools for the production-distribution-inventory-allocation-location problem in the pharmaceutical industry have been suggested by scholars $[64,65]$. Other studies propose the integration between reverse logistics and the other distribution processes $[66,67]$.

Scholars also focus particularly on the role of Industry 4.0 technologies, which are useful for improving the efficiency and effectiveness of distribution processes, reducing material, energy and water waste, and supporting the real-time monitoring [68,69]. Internet of things, big data, artificial intelligence, RFID, and blockchain are considered the most 
promising emerging technologies that will affect distribution and are regarded as key enablers for cleaner production and a circular economy [60,70,71]. All these technologies will allow firms to redesign SCs and improve their operational performance, enhancing efficiency in operations and material management and leading to cost savings [72].

Regarding the social dimension of sustainability, few studies suggest relationships with distribution processes, e.g., in terms of job opportunities [64,73].

Similarly to procurement, distribution is widely discussed within the literature on sustainable development, but robust argumentation on the direct relationship with SDGs is lacking. Exceptions are studies linking the food SC with SDGs 2, 7, 8, 9, 12, 13 and $16[74,75]$.

\section{Methodology, Data and Standardized Variables}

In this paper both literature research (Section 3) and descriptive statistical analysis (Section 4) are used to extract sustainable practices that can be implemented within SCs, and to link them to SDGs in order to show the performance achieved by SDG-oriented SCs associated with the 2030 Agenda. In this section a literature review has been carried out based on two different sources: an external one, represented by journal papers published in ranked journals (WoS and Scimago Q1 and Q2); and an internal one, i.e., a unique repository called "Business Process Framework for Sustainability", created and improved by the Department of Industrial Engineering at University of Salerno (Fisciano, Italy). In the next sub-sections, the explanation of the research process follows.

\subsection{Data Collection from Literature Review}

The data source for sustainable practices is the scientific literature on business management, specifically articles published in the most significant journals in the field of business, finance, economics, management, public administration, operations research, management science, and accounting, according to the ISI Web of Science and Scimago Journal Ranking, focusing on journals in Q1 and Q2. The list of scientific papers is extracted from SCOPUS, considering only those containing in the fields "title" and "keywords" words such as "sustainability", "sustainable" and "SDG".

The choice of employing such a source is motivated by the fact that the literature is rich in case studies on the role of sustainable development from the business perspective, which is the main focus of this research. Moreover, scientific literature is continuously updated and is a high-value source due to the external review process. Scientific articles, specifically in the form of case studies, allow for a detailed description of "how" sustainable development could be implemented.

Therefore, the project "Business Process Framework for Sustainability" carried out by the Department of Industrial Engineering of the University of Salerno (Italy) aims at collecting case studies from the literature in order to implement a repository of sustainable practices that could be suggested to companies. Differently from traditional literature reviews aiming at describing the state of the art to provide a scientific contribution, for this tool the analysis of each paper requires a formal and standardized procedure of registration within the repository. By employing a web application, experts in the field of sustainable development and business management extrapolate information about a sustainable practice by defining the association with sustainability-related elements, i.e., SDGs, and business-related elements, such as industry, business function, and impact. These variables are standardized to allow for comparability among practices. It is important to underscore that during data collection many documents were discarded since they did not provide sufficient information on the sustainable practice, which was necessary to label each variable. For this paper, the database built on papers published from January 2019 to May 2021 was analyzed, focusing on practices associated with business function "procurement" and "distribution".

Since reconfiguring SCs to support sustainable development requires radical changes and a reengineering of processes and investments, companies would be interested in sup- 
porting SDGs only if they could have the opportunity of improving their competitiveness in terms of either market or organizational performance. Therefore, at the basis of the choice of implementing SDG-oriented SCs, there is the need for the profit-oriented SC to achieve, at the same time, a positive impact on the business.

Consequently, the following business-related variables are considered:

- The industry of belongingness of the actors within the SC, since from the analysis of the literature it is evident that there are different opportunities within different industries;

- $\quad$ The SC processes associated with such practices, distinguishing between "procurement" and "distribution", with the first including all activities involving upstream partners, and the second including those engaging downstream actors;

- The positive business impact associated with the practice, which is independent of the concept of sustainability and refers to market and organizational performance that the focal company can achieve.

As to sustainability-related parameters, the database reports for each practice the formal association with SDGs, either directly declared within the document or assumed by the expert that analyzed the paper. Moreover, a second variable, "motivation", underscores the reason in terms of sustainability that could stimulate a firm to implement the sustainable practice. It refers to economic, social, and environmental issues that are widely treated by the literature on sustainable-driven innovation and sustainable development, such as "emissions reduction", "workplace health and safety" and "loss and waste reduction". Indeed, in most cases, the SDGs targets are expressed in terms that are quite far from the business language, whereas the "motivation" field included in the repository reports issues closer to corporate language. The following sections will better describe such variables.

\subsection{Business-Related Standardized Variables}

Three variables refer to the business context where the SC operates, i.e., industry, processes, and impact. As to the industry, practices can be useful for all industries and associated with the label "general"; otherwise, the specific industry is reported within the repository. Each one is also associated with the relevant sector, i.e., primary, manufacturing, and tertiary. Table 1 reports the list of industries under investigation. In order to ensure the definition of an exhaustive list, the categories of industries were compared with the Standard Industrial Classification Codes (Available online: www.siccode.com (accessed on 5 September 2021) to check its comprehensiveness). For the manufacturing sector, a general label was added to consider sustainable practices that are valid for all industrial applications.

Table 1. List of industries.

\begin{tabular}{ccc}
\hline Primary & Manufacturing & Tertiary \\
\hline & Manufacturing (general) & \\
& Automotive & \\
& Chemical & Digital \\
& Construction & Fashion \\
Agriculture & Electronics & Healthcare \\
Mining & Energy & Retail \\
& Food & Tourism and Hospitality \\
& Petroleum & Transport \\
& Pharmaceutical & \\
& Steel & \\
\hline
\end{tabular}

Source: our elaboration from the Standard Industrial Classification Codes.

Regarding the SC processes, two business functions are considered. First, the "procurement" function covers relationships with upstream partners and suppliers, such as order management and purchasing activities, raw materials management, and supplier 
evaluation and selection. Second, the "distribution" function is associated with logistics activities engaging downstream partners, such as transportation, delivery, warehouses, and inventory. Therefore, cooperation with 3PL, 4PL, carriers, distributors, wholesalers, and other logistic partners could be carried out by implementing sustainable approaches, for both forward and reverse logistics.

As to the impact on the business performance, Table 2 shows the list of labels that refer to either market or organizational performance that could be positively affected by the implementation of a sustainable practice managed by the focal firm. Such labels are entirely independent from SDGs, with the aim of creating an autonomous element for evaluating the opportunity of enhancing business performance. For instance, market performance refers to the growing performance towards stakeholders, such as investors and customers, whereas organizational performance can be associated with optimization of processes in terms of cost, time, and quality of physical flows, as well as regarding the management of information flows, while also considering positive impacts in terms of supply chain relationships management.

Table 2. Market vs. organizational performance.

\begin{tabular}{|c|c|}
\hline Market & Organizational \\
\hline $\begin{array}{c}\text { Attract investors } \\
\text { Brand reputation } \\
\text { Competitive advantage } \\
\text { Customer satisfaction } \\
\text { Product/service quality/value/differentiation } \\
\text { Revenues }\end{array}$ & $\begin{array}{c}\text { Costs reduction } \\
\text { Efficiency and productivity } \\
\text { Employee engagement } \\
\text { Energy efficiency } \\
\text { Flexibility } \\
\text { Information management } \\
\text { Innovation, knowledge, and technology } \\
\text { management } \\
\text { Supply chain relationships management } \\
\text { Time reduction }\end{array}$ \\
\hline
\end{tabular}

\subsection{Sustainability-Related Standardized Variables}

As to the variables associated with sustainable development, each practice is formally linked to at least one SDG in order to allow the specific contribution to the achievement of the 2030 Agenda to emerge. Moreover, since there is an evident missing link between business performance goals and SDGs, to add robustness to the analysis an additional label, "motivation", was considered. A list of 23 labels includes concepts of sustainable development and sustainable-oriented innovation that are widely employed in the literature and that are well-known for a firm. Indeed, the labels are associated with the traditional triple bottom line concept, with each being linked to at least one of the dimensions of sustainability, i.e., environmental, economic, and social. However, given that firms are prone to more traditional approaches, the repository also reports such information to enrich the triple bottom line by detailing the specific motivation that drives companies to implement sustainable development. For instance, almost all companies face the concept of "emissions reduction" but not all of them know that SDG 13 covers this issue. Within these labels, 9 refer to a unique dimension of sustainability (6 environmental, 2 social and 1 economic), 11 are related to two dimensions (7 economic-social, 2 environmentaleconomic and 2 environmental-social), and 3 are linked to all three dimensions (Table 3 ). For example, among environmental elements, "recycling and reuse-Circular economy" is particularly considered in the literature, as well as the reductions of emissions, loss and waste, and natural resources consumption. 
Table 3. Labels of the variable "motivation".

\begin{tabular}{|c|c|c|}
\hline Align with sustainability goals & $\$$ & (2) \\
\hline \multicolumn{3}{|l|}{ Biodiversity preservation } \\
\hline \multicolumn{3}{|l|}{ Collaboration for sustainability } \\
\hline \multicolumn{3}{|l|}{ Corporation survival and economic growth } \\
\hline \multicolumn{3}{|l|}{ Emissions reduction } \\
\hline \multicolumn{3}{|l|}{ Employee training and education } \\
\hline \multicolumn{3}{|l|}{ Fair trade } \\
\hline \multicolumn{3}{|l|}{ Fight corruption-Business ethics } \\
\hline \multicolumn{3}{|l|}{ Government regulation } \\
\hline \multicolumn{3}{|l|}{ Green certification } \\
\hline \multicolumn{3}{|l|}{ Human/workers' rights } \\
\hline \multicolumn{3}{|l|}{ Loss and waste reduction } \\
\hline \multicolumn{3}{|l|}{ Natural resources consumption reduction } \\
\hline \multicolumn{3}{|l|}{ Promote local culture and product } \\
\hline \multicolumn{3}{|l|}{ Promote sustainable consumer behavior } \\
\hline \multicolumn{3}{|l|}{ Provide access to resources } \\
\hline \multicolumn{2}{|l|}{ Public health } & \\
\hline \multicolumn{3}{|l|}{ Recycling and reuse-Circular economy } \\
\hline \multicolumn{3}{|l|}{ Respect for the surrounding area } \\
\hline \multicolumn{3}{|l|}{ Sustainability-Oriented Innovation (SOI) } \\
\hline \multicolumn{3}{|l|}{ Sustainable energy/material usage } \\
\hline \multicolumn{3}{|l|}{ Traceability and transparency } \\
\hline Workplace health and safety & 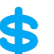 & C \\
\hline
\end{tabular}




\section{Analysis and Results}

Starting from the results of the literature review (Section 3), in this section descriptive statistics are presented and described. From the previous step, journal papers referred to the sustainable practices and published in ranked journals were collected overtime and selected from a repository called "Business Process Framework for Sustainability" owned by the Department of Industrial Engineering of the University of Salerno (Fisciano, Italy).

In this section the sample used in the statistical analysis is described. Moreover, descriptive statistics are presented with the aim to deeply understand the relationship between Business and Sustainability-Related variables and the procurement and distribution functions.

\subsection{Sample Description}

As of the end of July 2021, the repository consists of 5265 sustainable practices, considering all business functions. Taking into account only processes directly involved in SC relationships, i.e., "procurement" and "distribution" functions, the repository reports, respectively, 417 and 253 practices, for a total of 670 opportunities of implementing SDGoriented business practices within SCs. These practices were detected from a sample of 2764 papers. Such an activity required about 20 man-months of research by experts in the field of sustainable development and business management.

\subsection{Descriptive Statistics}

Figure 1 reports the count of sustainable practices by SDG. Only in a few cases are the linkages not available, therefore there is a significant coverage. As to procurement, the most significant goals are 12,13 and 17. The relevant association with Goal 12 underscores the role of procurement in terms of consumption of resources, mainly natural ones. For instance, firms can involve suppliers in eco-design and in using environmentally friendly materials to minimize the negative impacts of products and packaging on the ecology [76]. The association with Goal 17 underscores the strategic role of partnerships between buyers and suppliers to implement common practices supporting sustainable development. Firms can engage suppliers in the SC design to build environmentally and socially responsible partnerships [77], while also defining supplier codes of conduct under the buyer's governance [78]. SDG 13 reflects the positive implications that buyer-supplier relationships can have on environmental impact and climate change. For instance, buyers should use food grown, produced, processed, and consumed "locally" or "regionally", reducing the pollution associated with transportation [79].

Regarding distribution, the main focus is on SDG 13, since resource handling, transportation and physical flows in general have a great impact on the environment. Indeed, transportation is responsible for one-third of global greenhouse gas emissions. Examples of sustainable practices are the use of software and apps to plan routes to avoid congestion and traffic accidents to save fuel, lowering carbon emissions per product [80], and the adoption of vehicles with fuel-efficient engines to reduce $\mathrm{CO} 2$ emissions [81]. Moreover, distribution can also invest on SDG 9 for better management of logistics infrastructure and equipment, while also employing emerging technologies such as blockchain and internet of things $[82,83]$. Goal 12 covers about $20 \%$ of sustainable practices, with a focus on resource consumption, recycling, and waste management within warehouses and transportation activities.

Figure 2 reports the count of sustainable practices grouped by motivation. Within the procurement function, "collaboration for sustainability" covers about $25 \%$ of practices, additionally underscoring the potentialities of buyer-supplier relationships and cooperation for sustainable development. The collaboration is useful for all the sustainability dimensions. For instance, firms can dedicate resources to perform activities such as training, educating suppliers on sustainability and offering seminars on sustainability [84]. The relevance of environmental sustainability is expressed by the label "emissions reduction", which covers about $17 \%$ of sustainable practices, followed by circular economy approaches 
that particularly feature closed-loop SCs. Therefore, firms should use resources circularly not only at the individual level but also at the SC level. They have to build relationships with suppliers to share, reuse, and recycle resources circularly [85].

\begin{tabular}{ccc} 
Procurement & Goal & Distribution \\
6 & 1. No poverty & 1 \\
4 & 2. Zero hunger & 6 \\
7 & 3. Good health and well-being & 6 \\
7 & 4. Quality education & 0 \\
15 & 5. Gender equality & 0 \\
4 & 6. Clean water and sanitation & 0 \\
9 & 7. Affordable and clean energy & 3 \\
\hline 56 & 8. Decent work and economic growth & 23 \\
\hline 31 & 9. Industry, innovation and infrastructure & 53 \\
\hline 10 & 10. Reduced inequalities & 1 \\
\hline 8 & 11. Sustainable cities and communities & 26 \\
\hline 114 & 12. Responsible consumption and production & 52 \\
\hline 61 & 13. Climate action & 69 \\
\hline 0 & 14. Life below water & 5 \\
3 & 15. Life on land & 2 \\
7 & 16. Peace, justice and strong institutions & 1 \\
\hline 75 & 17. Partnerships & 5 \\
\hline
\end{tabular}

Figure 1. Count of sustainable practices by strategic development goals. The color of each row of the column "Goal" is the same of that used in the 2030 Agenda document.

\begin{tabular}{c} 
Procurement \\
9 \\
3 \\
97 \\
10 \\
71 \\
\hline 2 \\
8 \\
15 \\
5 \\
4 \\
40 \\
13 \\
34 \\
\hline 6 \\
1 \\
6 \\
1 \\
45 \\
1 \\
8 \\
3 \\
25 \\
10 \\
\hline
\end{tabular}

$\begin{array}{cc}\text { Motivation } & \text { Distribution } \\ \text { Align with sustainability goals } & 6 \\ \text { Biodiversity preservation } & 2 \\ \text { Collaboration for sustainability } & 5 \\ \text { Corporation survival and economic growth } & 11 \\ \text { Emissions reduction } & 122 \\ \text { Employee training and education } & 0 \\ \text { Fair trade } & 1 \\ \text { Fight corruption - business ethics } & 3 \\ \text { Government regulation } & 2 \\ \text { Green certification } & 0 \\ \text { Human/Workers rights } & 5 \\ \text { Loss and waste reduction } & 38 \\ \text { Natural resources consumption reduction } & 10 \\ \text { Promote local culture and product } & 1 \\ \text { Promote sustainable consumer behavior } & 0 \\ \text { Provide access to resources } & 4 \\ \text { Public health } & 0 \\ \text { Recycling and reuse - circular economy } & 22 \\ \text { Respect for the surrounding area } & 1 \\ \text { Sustainability-oriented innovation (SOI) } & 4 \\ \text { Sustainable energy/material usage } & 0 \\ \text { Traceability and Transparency } & 10 \\ \text { Workplace health and safety } & 6\end{array}$

Figure 2. Count of sustainable practices by motivation. 
As to distribution, about one-half of practices regards "emissions reduction", confirming the priority of environmental aspects, followed by "loss and waste reduction", which could engage all downstream actors of the SC, such as distributors, wholesalers, carriers, and logistic service providers. For example, the use of artificial intelligence in automated store ordering systems in supermarkets can curb food perishability [86].

In summary, grouping motivations into the three macro-categories (Figure 3), environmental motivations are a priority for both functions. Moreover, for procurement the combination of economic and social issues is particularly important, signaling the attention towards SC stakeholders and the sustainable growth of the business. For instance, firms should audit a supplier's locations and ensure non-employment of children and bonded labor [87] or implement blockchain for improving supply chain traceability and transparency towards stakeholders [88,89].

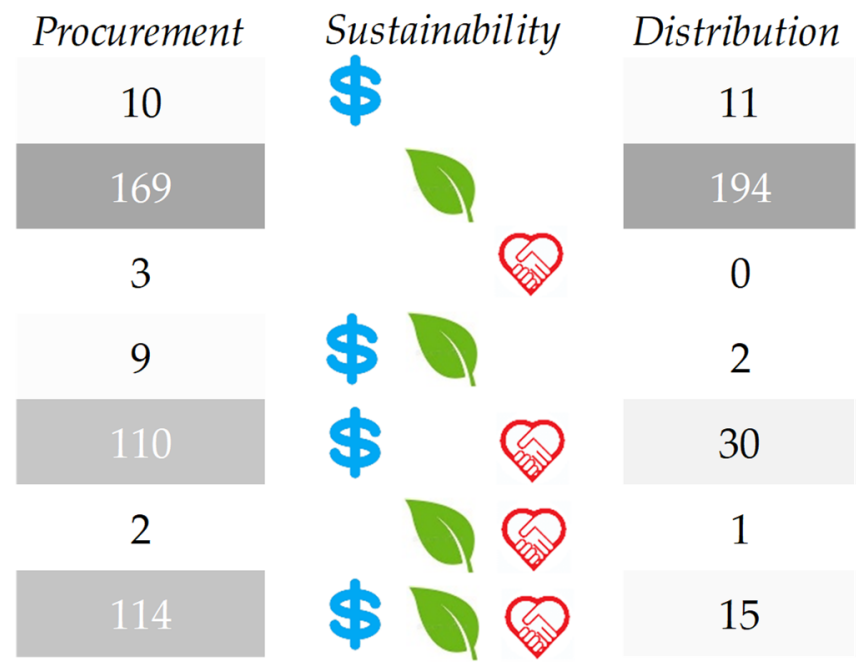

Figure 3. Count of sustainable practices by motivation macro-category.

Figure 4 reports the count of practices by industry. For procurement, about $40 \%$ of practices is associated with the label "general"; sustainable practices therefore cover all industries and sectors. Such a share is even higher for distribution (about 50\%), signaling that those sustainable approaches can be implemented in every company both upstream and downstream. In any case, the variable "industry" is significant, since the residual group of practices is widespread among specific industries. Apart from the opportunity of implementing practices within all manufacturing companies, for both procurement and distribution the food industry covers an important share. As to procurement, sustainable practices can be implemented for meat, pasta, cocoa beans, coffee, and eggs [48,90-92], whereas in distribution activities companies can implement methods for setting optimal target temperature for cold storage with sensor-based methods instead of traditional visual assessment [86] or use vacuum packaging to eliminate the presence of bacteria inside the package to improve the shelf life of products [52].

Grouping by sector, the manufacturing sector, which is the most common field for the implementation of SC management, is particularly prevailing (Figure 5).

Figure 6 shows the relationship between sustainability and improvements of business performance. Such a linkage is focal and at the center of this research, since SDG-oriented SCs also have to gain a competitive advantage from their support for the 2030 Agenda. In particular, the opportunity of improving brand reputation is the most common result within the procurement function, followed by efficiency and productivity enhancement and cost reduction. For instance, brand reputation can be enhanced by supporting suppliers in eco-design in order to manufacture eco-products that use environmentally friendly materials and packaging [76]. Moreover, well-managed social issues in the SC result 
in more efficiency and productivity among partners [93]; the optimization of resource consumption and the use of resources circularly also implies cost savings [85].

\begin{tabular}{|c|c|c|} 
Procurement & Industry & Distribution \\
\hline 172 & General & 121 \\
\hline 17 & Agriculture & 15 \\
11 & Mining & 0 \\
2 & Automotive & 1 \\
6 & Chemical & 0 \\
12 & Construction & 0 \\
9 & Electronics & 6 \\
4 & Energy & 0 \\
\hline 50 & Food & 36 \\
59 & Manufacturing (general) & 24 \\
5 & Petroleum & 0 \\
4 & Pharmaceutical & 5 \\
2 & Steel & 2 \\
11 & Textile & 0 \\
2 & Digital & 0 \\
27 & Fashion & 1 \\
2 & Healthcare & 0 \\
14 & Retail & 4 \\
8 & Tourism and hospitality & 0 \\
0 & Transportation & 38 \\
\hline
\end{tabular}

Figure 4. Count of sustainable practices by industry.

\begin{tabular}{|c|c|c|}
\hline Procurement & Sector & Distribution \\
\hline 172 & General & 121 \\
\hline 28 & Primary & 15 \\
\hline 164 & Manufacturing & 74 \\
\hline 53 & Tertiary & 43 \\
\hline
\end{tabular}

Figure 5. Count of sustainable practices by industry.

As to distribution, sustainable practices can also increase customer satisfaction, and produce efficiency and productivity enhancements as well as cost reduction. An example of customer satisfaction enhancement is the implementation of electronic waste take-back programs that are particularly appreciated by green customers [94].

As shown in the Figure 7, even though for both functions the most frequent impact is on specific market performances, by grouping practices by type of impact it emerges that organizational performance is prevalent and covers about two-thirds of sustainable practices. 


\begin{tabular}{c|c|c|} 
Procurement & Impact & Distribution \\
\hline 10 & Attract investors & 2 \\
\hline 4 & Brand reputation & 10 \\
\hline 22 & Competitive advantage & 6 \\
\hline 54 & Costs reduction & 51 \\
\hline 12 & Customer satisfaction & 63 \\
\hline 61 & Efficiency and productivity & 44 \\
\hline 5 & Employee engagement & 0 \\
\hline 15 & Energy efficiency & 13 \\
14 & Flexibility & 5 \\
15 & Information management & 5 \\
14 & Innovation, knowledge and technology management & 4 \\
8 & Product/service quality/value/differentiation & 6 \\
\hline 4 & Revenues & 6 \\
\hline 39 & Risk reduction & 7 \\
\hline 46 & Supply chain relationships management & 19 \\
\hline 4 & Time reduction & 12 \\
\hline
\end{tabular}

Figure 6. Count of sustainable practices by impact.

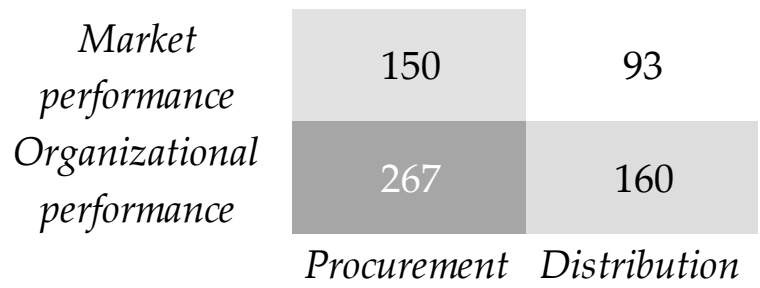

Figure 7. Count of sustainable practices by type of impact.

\subsection{The Relationship between Business and Sustainability-Related Variables and Procurement}

The following section explores the relationship between business and sustainabilityrelated variables within the procurement function. In particular, Figure 8 shows the distribution of practices for the couple SDG-sector. Some interesting insights emerge. General practices are focused on SDG 17, underscoring the role of buyer-supplier cooperation to support the 2030 Agenda. Goal 12 is important for the primary, manufacturing, and tertiary sectors, but Goal 8 is the most frequent within the tertiary sector. For example, the tourism industry supports SDG 8 by orientating customers towards ethical food consumption, promoting local culture, offering local and organic products, and purchasing food that is locally produced, eco-certified, or fair-trade $[79,95,96]$.

Regarding the relationship with business impact, SDGs are more associated with organizational performance improvements than with market ones (Figure 9).

As to the motivation for adopting a sustainable practice, "collaboration for sustainability" is most significant within the manufacturing sector, which is also represented by many occurrences in the field of "emissions reduction", "loss and waste reduction", "natural resources consumption reduction" and "recycling and reuse-Circular economy" (Figure 10). For instance, to reduce the use of natural resources, loss, and waste, firms can use the portion of the material supplied whose quality is below the conventional standard to make a co-product [73]. 


\begin{tabular}{lccccc} 
Goal & General & Primary & Manufacturing & Tertiary & Total \\
1. No poverty & 0 & 0 & 6 & 0 & 6 \\
2. Zero hunger & 0 & 1 & 3 & 0 & 4 \\
3. Good health and well-being & 4 & 0 & 2 & 1 & 7 \\
4. Quality education & 6 & 0 & 1 & 0 & 7 \\
5. Gender equality & 14 & 0 & 1 & 0 & 15 \\
6. Clean water and sanitation & 0 & 0 & 4 & 0 & 4 \\
7. Affordable and clean energy & 0 & 0 & 8 & 1 & 9 \\
\hline 8. Decent work and economic growth & 26 & 0 & 13 & 17 & 56 \\
\hline 9. Industry, innovation and infrastructure & 19 & 1 & 9 & 2 & 31 \\
10. Reduced inequalities & 6 & 0 & 4 & 0 & 10 \\
11. Sustainable cities and communities & 0 & 3 & 4 & 1 & 8 \\
12. Responsible consumption and production & 24 & 12 & 63 & 15 & 114 \\
13. Climate action & 27 & 2 & 23 & 9 & 61 \\
14. Life below water & 0 & 0 & 0 & 0 & 0 \\
15. Life on land & 0 & 1 & 1 & 1 & 3 \\
16. Peace, justice and strong institutions & 3 & 2 & 2 & 0 & 7 \\
17. Partnerships & 43 & 6 & 20 & 6 & 75 \\
\hline Total & 172 & 28 & 164 & 53 & 417
\end{tabular}

Figure 8. Relationship between SDGs and sector within the procurement function.

\begin{tabular}{lccc} 
Goal & Market & Organizational & Total \\
1. No poverty & 3 & 3 & 6 \\
2. Zero hunger & 0 & 4 & 4 \\
3. Good health and well-being & 2 & 5 & 7 \\
4. Quality education & 3 & 4 & 7 \\
5. Gender equality & 7 & 8 & 15 \\
6. Clean water and sanitation & 0 & 4 & 4 \\
7. Affordable and clean energy & 1 & 8 & 9 \\
8. Decent work and economic growth & 27 & 29 & 56 \\
9. Industry, innovation and infrastructure & 7 & 24 & 31 \\
10. Reduced inequalities & 4 & 6 & 10 \\
11. Sustainable cities and communities & 1 & 7 & 8 \\
12. Responsible consumption and production & 40 & 74 & 114 \\
13. Climate action & 24 & 37 & 61 \\
14. Life below water & 0 & 0 & 0 \\
15. Life on land & 2 & 1 & 3 \\
16. Peace, justice and strong institutions & 1 & 6 & 7 \\
17. Partnerships & 28 & 47 & 75 \\
\hline Total & 150 & 267 & 417
\end{tabular}

Figure 9. Relationship between SDGs and type of impact within the procurement function.

As to the tertiary sector, it is focused on the circular economy, signaling that not only manufacturing can contribute to green economy. In the retail industry, retailers and suppliers can create a closed cycle of products recycling with clothes obtained from packaging bottles [97,98]. It is necessary to underscore the importance of "human/workers rights" as a general motivation crossing all sectors-e.g., by auditing suppliers to eradicate forced labor [87] - and the need for implementing "traceability and transparency" towards stakeholders [46]. 


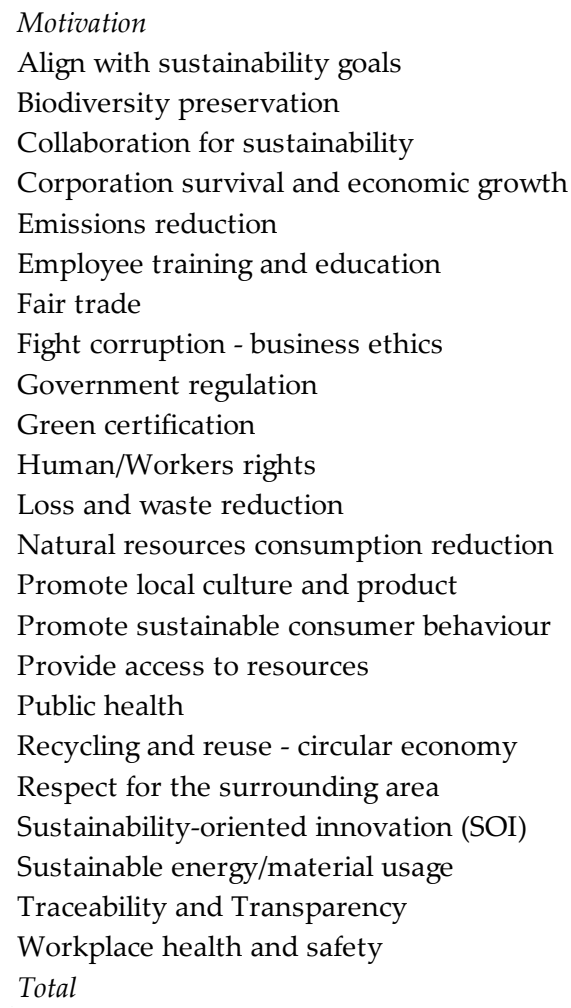

\begin{tabular}{|c|c|c|c|c|}
\hline General & Primary & Manufacturing & Tertiary & Total \\
\hline 1 & 3 & 3 & 2 & 9 \\
\hline 0 & 0 & 3 & 0 & 3 \\
\hline 51 & 5 & 30 & 11 & 97 \\
\hline 0 & 2 & 8 & 0 & 10 \\
\hline 33 & 1 & 28 & 9 & 71 \\
\hline 0 & 0 & 2 & 0 & 2 \\
\hline 0 & 0 & 8 & 0 & 8 \\
\hline 9 & 4 & 2 & 0 & 15 \\
\hline 0 & 0 & 5 & 0 & 5 \\
\hline 1 & 0 & 3 & 0 & 4 \\
\hline 36 & 0 & 4 & 0 & 40 \\
\hline 0 & 1 & 12 & 0 & 13 \\
\hline 2 & 3 & 23 & 6 & 34 \\
\hline 0 & 2 & 1 & 3 & 6 \\
\hline 0 & 0 & 1 & 0 & 1 \\
\hline 0 & 0 & 6 & 0 & 6 \\
\hline 0 & 0 & 1 & 0 & 1 \\
\hline 11 & 6 & 13 & 15 & 45 \\
\hline 0 & 0 & 0 & 1 & 1 \\
\hline 5 & 0 & 1 & 2 & 8 \\
\hline 1 & 0 & 2 & 0 & 3 \\
\hline 16 & 1 & 5 & 3 & 25 \\
\hline 6 & 0 & 3 & 1 & 10 \\
\hline 172 & 28 & 164 & 53 & 417 \\
\hline
\end{tabular}

Figure 10. Relationship between motivation and sector within the procurement function.

Regarding the relationship between motivation and type of impact (Figure 11), the following motivations affect both market and organizational performance: "collaboration for sustainability", "emissions reduction", "human-workers rights", "recycling and reuse-Circular economy". Moreover, organizational performance is also linked to "fight corruption-Business ethics", "natural resources consumption reduction" and "traceability and transparency". For example, an employee's opportunistic behaviors can be avoided by using merit as a criterion for promotions, salaries, and job benefits within the SC, and providing transparent access to information, [99]. Other examples of traceability allow for verifying whether the suppliers have been previously included in sanction lists because of an illegal activity [100].

\subsection{The Relationship between Business and Sustainability-Related Variables and Distribution}

In general, the distribution function is associated with SDGs 9, 11, and 13 (Figure 12). For instance, SDG 9 is associated with the implementation of enabling technologies to support green practices through emission control systems, GPS applications, real-time locating systems, warehouse management systems, logistics management systems, material management systems, enterprise resource planning, environmental database systems, environmental management systems, expert systems, learning management systems, order management systems, cloud computing, collaborative systems, content management systems, customer relationship management systems, environmental e-mails, environmental apps, mash-up applications, peer-to-peer resource sharing, social media, syndication systems, videocasting, and Wiki [101]. However, regarding the manufacturing sector, Goal 12 covers about $50 \%$ of the sustainable practices analyzed. Various practices are available to manage relationships with downstream partners and improve forecasting accuracy [102], optimize vehicle routing, improve the structure of refrigerated boxes, and use automated monitoring systems [103]. 
Motivation

Align with sustainability goals

Biodiversity preservation

Collaboration for sustainability

Corporation survival and economic growth

Emissions reduction

Employee training and education

Fair trade

Fight corruption - business ethics

Government regulation

Green certification

Human/Workers rights

Loss and waste reduction

Natural resources consumption reduction

Promote local culture and product

Promote sustainable consumer behaviour

Provide access to resources

Public health

Recycling and reuse - circular economy

Respect for the surrounding area

Sustainability-oriented innovation (SOI)

Sustainable energy/material usage

Traceability and Transparency

Workplace health and safety

Total

\begin{tabular}{ccc} 
Market & Organizational & Total \\
7 & 2 & 9 \\
3 & 0 & 3 \\
\hline 33 & 64 & 97 \\
3 & 7 & 10 \\
\hline 22 & 49 & 71 \\
\hline 1 & 1 & 2 \\
5 & 3 & 8 \\
5 & 10 & 15 \\
0 & 5 & 5 \\
2 & 2 & 4 \\
\hline 17 & 23 & 40 \\
\hline 4 & 9 & 13 \\
5 & 29 & 34 \\
5 & 1 & 6 \\
0 & 1 & 1 \\
3 & 3 & 6 \\
0 & 1 & 1 \\
\hline 16 & 29 & 45 \\
\hline 0 & 1 & 1 \\
3 & 5 & 8 \\
1 & 2 & 3 \\
9 & 16 & 25 \\
6 & 4 & 10 \\
150 & 267 & 417 \\
\hline & & \\
\hline
\end{tabular}

Figure 11. Relationship between motivation and type of impact within the procurement function.

\begin{tabular}{lc|c|c|c|c|}
\hline Goal & General & Primary & Manufacturing & Tertiary & Total \\
\hline 1. No poverty & 0 & 1 & 0 & 0 & 1 \\
\hline 2. Zero hunger & 2 & 1 & 3 & 0 & 6 \\
\hline 3. Good health and well-being & 4 & 0 & 0 & 2 & 6 \\
\hline 4. Quality education & 0 & 0 & 0 & 0 & 0 \\
\hline 5. Gender equality & 0 & 0 & 0 & 0 & 0 \\
6. Clean water and sanitation & 0 & 0 & 0 & 0 & 0 \\
\hline 7. Affordable and clean energy & 0 & 0 & 3 & 0 & 3 \\
\hline 8. Decent work and economic growth & 2 & 5 & 8 & 8 & 23 \\
\hline 9. Industry, innovation and infrastructure & 35 & 0 & 13 & 5 & 53 \\
\hline 10. Reduced inequalities & 0 & 1 & 0 & 0 & 1 \\
\hline 11. Sustainable cities and communities & 15 & 1 & 1 & 9 & 26 \\
\hline 12. Responsible consumption and production & 6 & 3 & 38 & 5 & 52 \\
\hline 13. Climate action & 53 & 2 & 7 & 7 & 69 \\
\hline 14. Life below water & 0 & 0 & 0 & 5 & 5 \\
15. Life on land & 0 & 1 & 1 & 0 & 2 \\
\hline 16. Peace, justice and strong institutions & 1 & 0 & 0 & 0 & 1 \\
\hline 17. Partnerships & 3 & 0 & 0 & 2 & 5 \\
\hline Total & 121 & 15 & 74 & 43 & 253
\end{tabular}

Figure 12. Relationship between SDGs and sector within the distribution function.

As to the business performance enhancement that it is possible to achieve from the support for the 2030 Agenda (Figure 13), SDGs 8, 9, 11, 12, and 13 are associated with organizational performance, while market performance is particularly supported by sustainable practices linked to Goals 9 and 13. Indeed, Goal 9 is associated with improvements in terms of competitive advantage, since innovation and technological development in distribution 
can provide market advantages: e.g., by optimizing container and transport operations, firms are able to attract more customers [59].

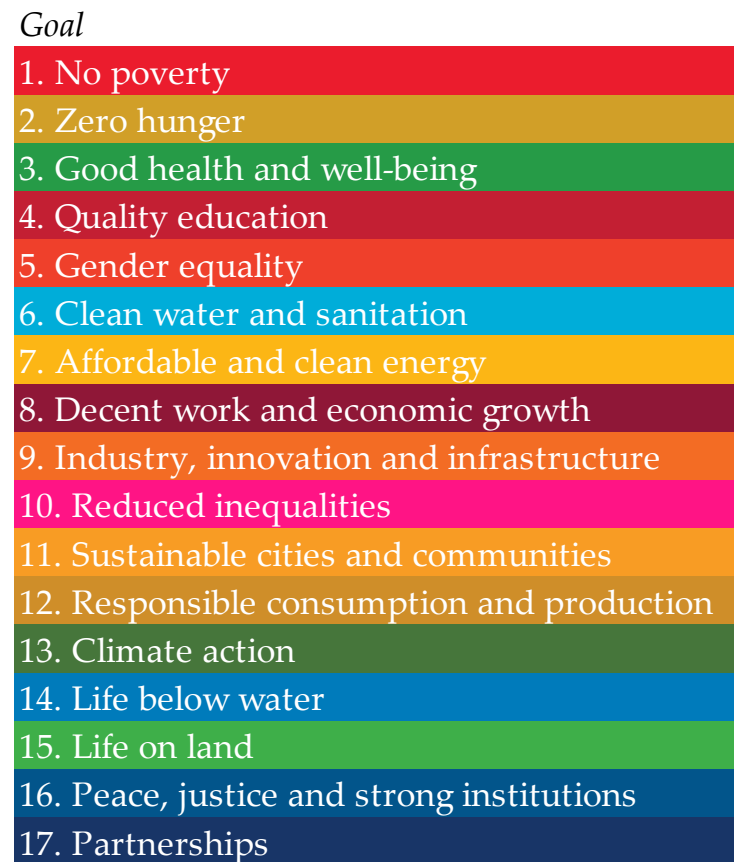

Total

\begin{tabular}{ccc} 
Market & Organizational & Total \\
1 & 0 & 1 \\
1 & 5 & 6 \\
1 & 5 & 6 \\
0 & 0 & 0 \\
0 & 0 & 0 \\
0 & 0 & 0 \\
0 & 3 & 3 \\
8 & 15 & 23 \\
\hline 26 & 27 & 53 \\
\hline 1 & 0 & 1 \\
4 & 22 & 26 \\
7 & 45 & 52 \\
\hline 38 & 31 & 69 \\
0 & 5 & 5 \\
2 & 0 & 2 \\
1 & 0 & 1 \\
3 & 2 & 5 \\
93 & 160 & 253
\end{tabular}

Figure 13. Relationship between SDGs and type of impact within the distribution function.

Figure 14 shows the relationship between the sector and the motivations for adopting sustainable distribution practices. A general linkage underscores the role of distribution for "emission reduction", that is also significant for the manufacturing and tertiary sectors. Moreover, as to manufacturing, "loss and waste reduction" and "recycling and reuse-Circular economy" are particularly linked to sustainable practices. Therefore, the environmental impact is prevailing on the other forms of sustainability. For instance, circular economy models can be implemented within the electronics industry [94], whereas loss and waste reduction features the food [102] and steel industries [55].

As to the linkage between motivation and impact on business performance, Figure 15 shows that "emissions reduction" is predominant for sustainable practices that improve both market and organizational performances. As to the latter, positive enhancements are also linked to environmental elements such as "natural resources consumption reduction", "recycling and reuse-Circular economy" and "loss and waste reduction". In particular, among the natural resources linked to sustainable practices in distribution processes, the opportunities for the water industry are significant $[69,104]$. 


\section{Motivation}

Align with sustainability goals

Biodiversity preservation

Collaboration for sustainability

Corporation survival and economic growth

Emissions reduction

Fair trade

Fight corruption - business ethics

Government regulation

Human/Workers rights

Loss and waste reduction

Natural resources consumption reduction

Promote local culture and product

Provide access to resources

Recycling and reuse - circular economy

Respect for the surrounding area

Sustainability-oriented innovation (SOI)

Traceability and Transparency

Workplace health and safety

Total

$\begin{array}{ccccc}\text { General } & \text { Primary } & \text { Manufacturing } & \text { Tertiary } & \text { Total } \\ 2 & 0 & 3 & 1 & 6 \\ 0 & 0 & 0 & 2 & 2 \\ 4 & 0 & 0 & 1 & 5 \\ 0 & 3 & 3 & 5 & 11 \\ 85 & 3 & 12 & 22 & 122 \\ 0 & 1 & 0 & 0 & 1 \\ 3 & 0 & 0 & 0 & 3 \\ 1 & 0 & 0 & 1 & 2 \\ 2 & 3 & 0 & 0 & 5 \\ 5 & 0 & 27 & 6 & 38 \\ 6 & 1 & 2 & 1 & 10 \\ 0 & 1 & 0 & 0 & 1 \\ 0 & 0 & 4 & 0 & 4 \\ 5 & 0 & 17 & 0 & 22 \\ 0 & 0 & 1 & 0 & 1 \\ 0 & 0 & 3 & 1 & 4 \\ 3 & 3 & 2 & 2 & 10 \\ 5 & 0 & 0 & 1 & 6 \\ 121 & 15 & 74 & 43 & 253\end{array}$

Figure 14. Relationship between motivation and sector within the distribution function.

Motivation
Align with sustainability goals
Biodiversity preservation
Collaboration for sustainability
Corporation survival and economic growth
Emissions reduction
Fair trade
Fight corruption - business ethics
Government regulation
Human/Workers rights
Loss and waste reduction
Natural resources consumption reduction
Promote local culture and product
Provide access to resources
Recycling and reuse - circular economy
Respect for the surrounding area
Sustainability-oriented innovation (SOI)
Traceability and Transparency
Workplace health and safety
Total

$\begin{array}{ccc}\text { Market } & \text { Organizational } & \text { Total } \\ 1 & 5 & 6 \\ 0 & 2 & 2 \\ 3 & 2 & 5 \\ 4 & 7 & 11 \\ 64 & 58 & 122 \\ 1 & 0 & 1 \\ 1 & 2 & 3 \\ 0 & 2 & 2 \\ 5 & 0 & 5 \\ 3 & 35 & 38 \\ 0 & 10 & 10 \\ 1 & 0 & 1 \\ 0 & 4 & 4 \\ 5 & 17 & 22 \\ 1 & 0 & 1 \\ 0 & 4 & 4 \\ 2 & 8 & 10 \\ 2 & 4 & 6 \\ 93 & 160 & 253\end{array}$

Figure 15. Relationship between motivation and type of impact within the distribution function.

\section{Discussions}

Starting from the previous sections, discussions about the academic (theoretical contribution and methodological issues) and practical (managerial) sides are presented below.

\subsection{Theoretical Contribution}

From the analysis of the specific opportunities of implementing sustainable practices within SCs, there is an evident positive relationship between sustainable development and SC performance enhancement. The research demonstrates that sustainable SCs and SDG-oriented SCs can implement business practices for procurement and distribution activities that may positively contribute to the overall performance. Such opportunities 
can be affected by the features of the relevant industry and depend on the SC functionprocurement or distribution-where they are implemented. In any case, the research contributes to the literature on SC management by providing a direct linkage between SDGs and SC performance, proposing hundreds of possible applications. This means that firms can continue innovating and improving their business performance by reengineering processes to maximize profits, but also by contributing to the achievement of SDGs. In line with the scientific literature that began with the study of the linkage between SDGs and firms, this research suggests such a linkage within various industries and clarifies where there are the main opportunities for implementation and what those opportunities are. Therefore, from the theoretical perspective the research contributes to the initial SDG framework by providing formal sustainable practices that clarify "how" to implement sustainability and can be employed to support the 2030 Agenda. Indeed, a comprehensive and direct linkage between SDGs and SCs is lacking in the literature. This research shows that by looking at SCs from the perspective of the achievement of SDGs, it is possible to clarify how companies and SCs could formally contribute to the 2030 Agenda. Such a formal relationship could not be captured by considering the traditional triple bottom line approach. Even though it is simpler to understand and implement within companies' sustainability frameworks, it is necessary to overcome such a concept and to refer to SDGs to truly associate companies' activities to the contribution in the field of sustainability. Such complexity in linking SDGs and SCs is probably the motivation for the literature's focus on the traditional linkage with environmental, economic, and social sustainability. Indeed, SDGs have been defined by "policy makers"; they therefore suffer from the macroeconomic perspective adopted by the United Nations, which is not easy to convert into the perspective of the private sector. Therefore, this research tries to deduce the linkage with SDGs from sustainable practices available to firms to portray the state of the art of the contribution of SCs to the achievement of the 2030 Agenda. SDG-oriented SCs will have a formal role within the 2030 Agenda, by defining the specific SDGs on which they will focus and also identifying priorities of implementation on specific targets and goals. However, understanding that firms are prone to more traditional approaches, the repository also reports information about the field motivation, for a more exhaustive analysis of the state of the art on the SC contribution to sustainability issues. Such information enriches the analysis since it is based on a list of very different elements that can be linked to one or more types of sustainability according to the triple bottom line concept. The suggested taxonomy underscores the need of approaching the triple bottom line by entering into details of the specific motivation that drives companies to implement sustainable development. For instance, within the environmental dimension of sustainability there are very different elements: e.g., preserving biodiversity is a goal very different from reducing emissions. In addition to the suggestion to revise the traditional triple bottom line concept, it is important to underscore that the field motivation, being associated with such a concept, plays the role of liaison between sustainable SCs based on the SDG concept and those based on the triple bottom line concept.

Moreover, although the literature focuses on the environmental dimension of sustainability, this research demonstrates that there are also many opportunities for supporting its social dimension and most SDGs related to social issues. Therefore, SCs can be the perfect locus for firms to change their processes and practices and cooperate with partners to support all SDGs, overcoming the limited concepts of green SCs and closed-loop SCs. Firms without the engagement of upstream and downstream partners could not assume the responsibility of carrying out a sustainable development strategy, since a joint effort of all SC actors and stakeholders is necessary.

From the analysis of the repository, differences emerge between the procurement and distribution functions. This means that SCs should implement an overall sustainable strategy, but different practices should feature the relationship of the focal firm with upstream and downstream partners. 


\subsection{Methodological Issues}

The analysis was performed thanks to the implementation of a repository of practices that are associated with standardized variables and labels. This allow for standardized data collection from the scientific literature, aiming at classifying case studies and implementation proposals by scholars to collect a list of sustainable practices that could be concretely implemented within SCs, covering all dimensions of sustainability and providing a direct linkage with SDGs. Therefore, the role of the experts that have studied in detail each suggested practice and critically associated it to the various labels of the repository is crucial. The repository can be continuously updated by adding new sustainable practices that will be detected from future literature contributions. A similar methodology can be employed to study other documents, such as a firm's sustainability reports, to enrich the repository and diversify the sources from which practices are detected.

An additional remark refers to the definition of the variable "motivation". The list of labels assigned to the variable are the result of the analysis of about 3000 scientific papers, thus confirming its robustness. Such concepts can also be useful for associating sustainable development with business practices and activities. Indeed, despite the aim of directly linking SC performance with SDGs, it is also necessary to associate sustainable practices with concepts that are closer to firms' language and well-known within business practices.

\subsection{Practical and Managerial Implications and Recommendations}

Data collected from the project "Business Process Framework for Sustainability" carried out by the Department of Industrial Engineering of the University of Salerno (Italy) represent a repository of sustainable practices that can be concretely used as a reference for companies and SCs that intend to support the 2030 Agenda. The repository was developed imagining that in the future firms can access it to find new opportunities of implementation of sustainable practices for their SC. Indeed, the database can support firms in selecting sustainable practices that are available for their business, while also considering business impact, industry belongingness, and SC function, i.e., procurement or distribution. This could simplify the implementation of SDG-oriented SCs, since companies could take into account the implications in terms of the 2030 Agenda when they decide to reengineer and reorganize their internal processes and activities, so that the choice of changing SC operations will be affected not only by business-related criteria but also by sustainability-related ones. Moreover, from the list of practices that could be potentially implemented, firms will select those fitting with both the desired business performance improvement and the SDG that they intend to support. Companies can select practices in consideration of SDG prioritization strategies and be aware of their contribution to the 2030 Agenda by investing in specific sustainability areas. This will also simplify their sustainability reporting, which can be linked to the 2030 Agenda. By employing appropriate sustainability metrics, they will measure the real contribution of their SC operations. The research group plans to publish the repository by 2022, to allow companies to access it.

Similarly, the database could be useful for researchers, policy makers, and experts in the field of sustainable development to find, consider, and study the relationship between SDGs and SC performance.

\section{Conclusions and Limitations}

The paper aimed at analyzing the state of the art of sustainable practices within SCs by employing data collected from the repository "Business Process Framework for Sustainability" owned by the Department of Industrial Engineering of the University of Salerno (Fisciano, Italy). From the study of the practices that can be implemented for cooperation activities with upstream and downstream SC partners, it emerged that companies have many opportunities for both enhancing their performance and supporting the 2030 Agenda. The research demonstrates that both procurement and distribution processes could be reengineered by implementing sustainable approaches considering all three dimensions of sustainability. Differences emerge in terms of number of opportunities, 
depending on motivations for implementing sustainable practices, industry and processes, performance achieved, and SDGs pursued.

However, the repository has various limitations. First, there is no guarantee that the implementation of the suggested practices within a SC will lead to the expected results, since some additional business-related elements could affect the likelihood of success. Second, despite the wide number of scientific papers that have been analyzed, it is necessary to extend the study to additional thousands of scientific documents to add further robustness to the repository and collect a wider number of sustainable practices. Third, the range of statistical analyses that it is possible to perform on such a repository is limited, since the variables are qualitative and nominal.

Consequently, future research will focus on the enlargement of the size of the repository, while also considering other sources, such as firms' sustainability reports. Moreover, by 2022 the repository will be published; therefore, a significant effort will be necessary to implement a web application to allow researchers and companies easy access to the database.

Author Contributions: Conceptualization, A.C., F.M. and M.C.; data curation, A.C.; formal analysis, F.M. and A.C.; methodology, M.P. and A.C.; project administration, M.C.; supervision, F.M., M.C. and C.D.R.; validation, M.P., F.M., M.C. and C.D.R.; writing — original draft, A.C. and M.P.; writingreview and editing, F.M. and C.D.R. All authors have read and agreed to the published version of the manuscript.

Funding: This research received no external funding.

Institutional Review Board Statement: Not applicable.

Informed Consent Statement: Not applicable.

Data Availability Statement: Not applicable.

Conflicts of Interest: The authors declare no conflict of interest.

\section{References}

1. Botti, A.; Monda, A.; Pellicano, M.; Torre, C. The re-conceptualization of the port supply chain as a smart port service system: The case of the port of salerno. Systems 2017, 5, 35. [CrossRef]

2. Brundtland, G.H. Our Common Future-The World Commission on Environment and Development; Oxford University Press: Oxford, UK, 1987.

3. Ahmadi, H.B.; Lo, H.W.; Gupta, H.; Kusi-Sarpong, S.; Liou, J.J.H. An integrated model for selecting suppliers on the basis of sustainability innovation. J. Clean. Prod. 2020, 277, 123261. [CrossRef]

4. Quattrociocchi, B.; Mercuri, F.; Perano, M.; Calabrese, M. Tourism supply chain \& strategic partnerships for managing the complexity in tourism industry. Enl. Tour. A Pathmaking J. 2017, 7, 62-93. [CrossRef]

5. Yu, C.; Shao, Y.; Wang, K.; Zhang, L. A group decision making sustainable supplier selection approach using extended TOPSIS under interval-valued Pythagorean fuzzy environment. Expert Syst. Appl. 2019, 121, 1-17. [CrossRef]

6. Song, Y.; Cai, J.; Feng, T. The influence of green supply chain integration on firm performance: A contingency and configuration perspective. Sustainability 2017, 9, 763. [CrossRef]

7. Mazzucchelli, A.; Gurioli, M.; Graziano, D.; Quacquarelli, B.; Aouina-Mejri, C. How to fight against food waste in the digital era: Key factors for a successful food sharing platform. J. Bus. Res. 2020, 124, 47-58. [CrossRef]

8. Caputo, F.; Scuotto, V.; Papa, A.; del Giudice, M. Dalla coercizione per la sostenibilit\&agrave; all'impegno sociale: Il ruolo della responsabilit\&agrave; sociale d'impresa. Corp. Gov. Res. Dev. Stud. 2021, 2, 15-31. [CrossRef]

9. del Giudice, M.; Khan, Z.; de Silva, M.; Scuotto, V.; Caputo, F.; Carayannis, E. The microlevel actions undertaken by ownermanagers in improving the sustainability practices of cultural and creative small and medium enterprises: A United KingdomItaly comparison. J. Organ. Behav. 2017, 38, 1396-1414. [CrossRef]

10. Pontieri, P.; Mennini, F.S.; Magni, D.; Fiano, F.; Scuotto, V.; Papa, A.; Aletta, M.; Del Giudice, L. Sustainable open innovation for the agri-food system: Sorghum as healthy food to deal with environmental challenges. Br. Food J. 2021. ahead of print. [CrossRef]

11. van der Waal, J.W.H.; Thijssens, T.; Maas, K. The innovative contribution of multinational enterprises to the Sustainable Development Goals. J. Clean. Prod. 2020, 285, 125319. [CrossRef]

12. van der Waal, J.W.H.; Thijssens, T. Corporate involvement in Sustainable Development Goals: Exploring the territory. J. Clean. Prod. 2019, 252, 119625. [CrossRef]

13. Zavyalova, E.; Studenikin, N.; Starikova, E. Business participation in implementation of socially oriented sustainable development goals in countries of central Asia and the Caucasus region. Cent. Asia Cauc. 2018, 19, 56-63. 
14. Fathollahi-Fard, A.M.; Ahmadi, A.; Al-e-Hashem, S.M.J.M. Sustainable closed-loop supply chain network for an integrated water supply and wastewater collection system under uncertainty. J. Environ. Manag. 2020, 275, 111277. [CrossRef] [PubMed]

15. Zhou, D.; Meinke, H.; Wilson, M.; Marcelis, L.F.M.; Heuvelink, E. Towards delivering on the sustainable development goals in greenhouse production systems. Resour. Conserv. Recycl. 2021, 169, 105379. [CrossRef]

16. Fraser, J. Creating shared value as a business strategy for mining to advance the United Nations Sustainable Development Goals. Extr. Ind. Soc. 2019, 6, 788-791. [CrossRef]

17. Fallahpour, A.; Wong, K.Y.; Rajoo, S.; Fathollahi-Fard, A.M.; Antucheviciene, J.; Nayeri, S. An integrated approach for a sustainable supplier selection based on Industry 4.0 concept. Environ. Sci. Pollut. Res. 2021. [CrossRef]

18. Scheyvens, R.; Banks, G.; Hughes, E. The Private Sector and the SDGs: The Need to Move Beyond 'Business as Usual'. Sustain. Dev. 2016, 24, 371-382. [CrossRef]

19. Calabrese, A.; Costa, R.; Ghiron, N.L.; Tiburzi, L.; Pedersen, E.R.G. How sustainable-orientated service innovation strategies are contributing to the sustainable development goals. Technol. Forecast. Soc. Chang. 2021, 169, 120816. [CrossRef]

20. Adams, R.; Jeanrenaud, S.; Bessant, J.; Denyer, D.; Overy, P. Sustainability-oriented Innovation: A Systematic Review. Int. J. Manag. Rev. 2016, 18, 180-205. [CrossRef]

21. Varriale, V.; Cammarano, A.; Michelino, F.; Caputo, M. The role of supplier innovation performance and strategies on the smartphone supply market. Eur. Manag. J. 2021, in press. [CrossRef]

22. Cammarano, A.; Michelino, F.; Vitale, M.P.; la Rocca, M.; Caputo, M. Technological Strategies and Quality of Invention: The Role of Knowledge Base and Technical Applications. IEEE Trans. Eng. Manag. 2020, 1-17. [CrossRef]

23. Cammarano, A.; Michelino, F.; Lamberti, E.; Caputo, M. Investigating technological strategy and relevance of knowledge domains in R\&D collaborations. Int. J. Technol. Manag. 2019, 79, 60-83. [CrossRef]

24. Cammarano, A.; Michelino, F.; Caputo, M. Open innovation practices for knowledge acquisition and their effects on innovation output. Technol. Anal. Strat. Manag. 2019, 31, 1297-1313. [CrossRef]

25. Cammarano, A.; Caputo, M.; Lamberti, E.; Michelino, F. R\&D Collaboration Strategies for Innovation: An Empirical Study Through Social Network Analysis. Int. J. Innov. Technol. Manag. 2017, 14, 1740001. [CrossRef]

26. Muff, K.; Kapalka, A.; Dyllick, T. The Gap Frame-Translating the SDGs into relevant national grand challenges for strategic business opportunities. Int. J. Manag. Educ. 2017, 15, 363-383. [CrossRef]

27. Raith, M.G.; Siebold, N. Building Business Models around Sustainable Development Goals. J. Bus. Models 2018, 6, 71-77. [CrossRef]

28. Williams, A.; Whiteman, G.; Parker, J.N. Backstage Interorganizational Collaboration: Corporate Endorsement of the Sustainable Development Goals. Acad. Manag. Discov. 2019, 5, 367-395. [CrossRef]

29. Zimon, D.; Tyan, J.; Sroufe, R. Drivers of sustainable supply chain management: Practices to alignment with un sustainable development goals. Int. J. Qual. Res. 2020, 14, 219-236. [CrossRef]

30. Blair, M.J.; Gagnon, B.; Klain, A.; Kulišić, B. Contribution of biomass supply chains for bioenergy to sustainable development goals. Land 2021, 10, 181. [CrossRef]

31. Russell, E.; Lee, J.; Clift, R. Can the SDGs provide a basis for supply chain decisions in the construction sector? Sustainability 2018, 10, 629. [CrossRef]

32. Genc, T.S. Implementing the United Nations sustainable development Goals to supply chains with behavioral consumers. Ann Oper. Res. 2021, 1-32. [CrossRef]

33. Althaf, S.; Babbitt, C.W. Disruption risks to material supply chains in the electronics sector. Resour. Conserv. Recycl. 2020, 167, 105248. [CrossRef]

34. Mina, H.; Kannan, D.; Gholami-Zanjani, S.M.; Biuki, M. Transition towards circular supplier selection in petrochemical industry: A hybrid approach to achieve sustainable development goals. J. Clean. Prod. 2020, 286, 125273. [CrossRef]

35. Haeri, S.A.S.; Rezaei, J. A grey-based green supplier selection model for uncertain environments. J. Clean. Prod. 2019, 221, 768-784. [CrossRef]

36. Gao, H.; Ju, Y.; Gonzalez, E.D.R.S.; Zhang, W. Green supplier selection in electronics manufacturing: An approach based on consensus decision making. J. Clean. Prod. 2020, 245, 118781. [CrossRef]

37. Fallahpour, A.; Yazdani, M.; Mohammed, A.; Wong, K.Y. Green sourcing in the era of industry 4.0: Towards green and digitalized competitive advantages. Ind. Manag. Data Syst. 2021, 121, 1997-2025. [CrossRef]

38. Lahri, V.; Shaw, K.; Ishizaka, A. Sustainable supply chain network design problem: Using the integrated BWM, TOPSIS, possibilistic programming, and $\varepsilon$-constrained methods. Expert Syst. Appl. 2020, 168, 114373. [CrossRef]

39. Bai, C.; Kusi-Sarpong, S.; Ahmadi, H.B.; Sarkis, J. Social sustainable supplier evaluation and selection: A group decision-support approach. Int. J. Prod. Res. 2019, 57, 7046-7067. [CrossRef]

40. Schiessl, A.; Müller, R.; Volk, R.; Schultmann, F. Site-specific environmental impact assessment as a basis for supplier selectionsexemplary application to aluminum. J. Clean. Prod. 2021, 290, 125703. [CrossRef]

41. Wu, C.; Lin, C.; Barnes, D.; Zhang, Y. Partner selection in sustainable supply chains: A fuzzy ensemble learning model. J. Clean. Prod. 2020, 275, 123165. [CrossRef]

42. Sultan, F.A.; Routroy, S.; Thakur, M. A simulation-based performance investigation of downstream operations in the Indian Surimi Supply Chain using environmental value stream mapping. J. Clean. Prod. 2020, 286, 125389. [CrossRef] 
43. Lahane, S.; Kant, R.; Shankar, R. Circular supply chain management: A state-of-art review and future opportunities. J. Clean. Prod. 2020, 258, 120859. [CrossRef]

44. Fatimah, Y.A.; Govindan, K.; Murniningsih, R.; Setiawan, A. Industry 4.0 based sustainable circular economy approach for smart waste management system to achieve sustainable development goals: A case study of Indonesia. J. Clean. Prod. 2020, $269,122263$. [CrossRef]

45. Nasr, A.K.; Tavana, M.; Alavi, B.; Mina, H. A novel fuzzy multi-objective circular supplier selection and order allocation model for sustainable closed-loop supply chains. J. Clean. Prod. 2020, 287, 124994. [CrossRef]

46. Wan, X.; Liu, X.; Du, Z.; Du, Y. A novel model used for assessing supply chain sustainability integrating the ANP and ER approaches and its application in marine ranching. J. Clean. Prod. 2020, 279, 123500. [CrossRef]

47. Mirzaee, H.; Naderi, B.; Pasandideh, S.H.R. A preemptive fuzzy goal programming model for generalized supplier selection and order allocation with incremental discount. Comput. Ind. Eng. 2018, 122, 292-302. [CrossRef]

48. Sodhi, M.M.S.; Tang, C.S. Extending AAA Capabilities to Meet PPP Goals in Supply Chains. Prod. Oper. Manag. 2020, $30,625-632$. [CrossRef]

49. Silvestre, B.S.; Ţîrcă, D.M. Innovations for sustainable development: Moving toward a sustainable future. J. Clean. Prod. 2018, 208, 325-332. [CrossRef]

50. Govindan, K.; Shankar, K.M.; Kannan, D. Achieving sustainable development goals through identifying and analyzing barriers to industrial sharing economy: A framework development. Int. J. Prod. Econ. 2020, 227, 107575. [CrossRef]

51. Malik, A.; Lafortune, G.; Carter, S.; Li, M.; Lenzen, M.; Kroll, C. International spillover effects in the EU's textile supply chains: A global SDG assessment. J. Environ. Manag. 2021, 295, 113037. [CrossRef]

52. Spreafico, C.; Russo, D. A sustainable cheese packaging survey involving scientific papers and patents. J. Clean. Prod. 2021, 293, 126196. [CrossRef]

53. Chen, Z.S.; Zhang, X.; Govindan, K.; Wang, X.J.; Chin, K.S. Third-party reverse logistics provider selection: A computational semantic analysis-based multi-perspective multi-attribute decision-making approach. Expert Syst. Appl. 2020, 166, 114051. [CrossRef]

54. Govindan, K.; Kadziński, M.; Ehling, R.; Miebs, G. Selection of a sustainable third-party reverse logistics provider based on the robustness analysis of an outranking graph kernel conducted with ELECTRE I and SMAA. Omega 2019, 85, 1-15. [CrossRef]

55. Pourmehdi, M.; Paydar, M.M.; Asadi-Gangraj, E. Scenario-based design of a steel sustainable closed-loop supply chain network considering production technology. J. Clean. Prod. 2020, 277, 123298. [CrossRef]

56. Mojtahedi, M.; Fathollahi-Fard, A.M.; Tavakkoli-Moghaddam, R.; Newton, S. Sustainable vehicle routing problem for coordinated solid waste management. J. Ind. Inf. Integr. 2021, 23, 100220. [CrossRef]

57. Baral, N.R.; Asher, Z.D.; Trinko, D.; Sproul, E.; Quiroz-Arita, C.; Quinn, J.C.; Bradley, T.H. Biomass feedstock transport using fuel cell and battery electric trucks improves lifecycle metrics of biofuel sustainability and economy. J. Clean. Prod. 2020, $279,123593$. [CrossRef]

58. Liu, X.; Elgowainy, A.; Vijayagopal, R.; Wang, M. Well-to-Wheels Analysis of Zero-Emission Plug-In Battery Electric Vehicle Technology for Medium- and Heavy-Duty Trucks. Environ. Sci. Technol. 2020, 55, 538-546. [CrossRef]

59. Karakas, S.; Acar, A.Z.; Kirmizi, M. Development of a multidimensional performance evaluation model for container terminals at Marmara Sea. Res. Transp. Bus. Manag. 2020, 37, 100498. [CrossRef]

60. Dutta, P.; Talaulikar, S.; Xavier, V.; Kapoor, S. Fostering reverse logistics in India by prominent barrier identification and strategy implementation to promote circular economy. J. Clean. Prod. 2021, 294, 126241. [CrossRef]

61. Kumar, A.; Wasan, P.; Luthra, S.; Dixit, G. Development of a framework for selecting a sustainable location of waste electrical and electronic equipment recycling plant in emerging economies. J. Clean. Prod. 2020, 277, 122645. [CrossRef]

62. Mishra, U.; Wu, J.Z.; Sarkar, B. Optimum sustainable inventory management with backorder and deterioration under controllable carbon emissions. J. Clean. Prod. 2020, 279, 123699. [CrossRef]

63. Mehmann, J.; Teuteberg, F. The fourth-party logistics service provider approach to support sustainable development goals in transportation-A case study of the German agricultural bulk logistics sector. J. Clean. Prod. 2016, 126, 382-393. [CrossRef]

64. Goodarzian, F.; Taleizadeh, A.A.; Ghasemi, P.; Abraham, A. An integrated sustainable medical supply chain network during COVID-19. Eng. Appl. Artif. Intell. 2021, 100, 104188. [CrossRef] [PubMed]

65. Goodarzian, F.; Hosseini-Nasab, H.; Fakhrzad, M.B. A multi-objective sustainable medicine supply chain network design using a novel hybrid multi-objective metaheuristic algorithm. Int. J. Eng. 2020, 33, 1986-1995. [CrossRef]

66. Cao, S.; Liao, W.; Huang, Y. Heterogeneous fleet recyclables collection routing optimization in a two-echelon collaborative reverse logistics network from circular economic and environmental perspective. Sci. Total Environ. 2020, 758, 144062. [CrossRef]

67. Ben-Daya, M.; As'ad, R.; Nabi, K.A. A single-vendor multi-buyer production remanufacturing inventory system under a centralized consignment arrangement. Comput. Ind. Eng. 2019, 135, 10-27. [CrossRef]

68. Holmström, J.; Holweg, M.; Lawson, B.; Pil, F.K.; Wagner, S.M. The digitalization of operations and supply chain management: Theoretical and methodological implications. J. Oper. Manag. 2019, 65, 728-734. [CrossRef]

69. Jagtap, S.; Garcia-Garcia, G.; Rahimifard, S. Optimisation of the resource efficiency of food manufacturing via the Internet of Things. Comput. Ind. 2021, 127, 103397. [CrossRef]

70. Shayganmehr, M.; Kumar, A.; Garza-Reyes, J.A.; Moktadir, M.A. Industry 4.0 enablers for a cleaner production and circular economy within the context of business ethics: A study in a developing country. J. Clean. Prod. 2021, 281, 125280. [CrossRef] 
71. Varriale, V.; Cammarano, A.; Michelino, F.; Caputo, M. New organizational changes with blockchain: A focus on the supply chain. J. Organ. Chang. Manag. 2021, 34, 420-438. [CrossRef]

72. Mastos, T.D.; Nizamis, A.; Terzi, S.; Gkortzis, D.; Papadopoulos, A.; Tsagkalidis, N.; Ioannidis, D.; Votis, K.; Tzovaras, D. Introducing an application of an industry 4.0 solution for circular supply chain management. J. Clean. Prod. 2021, $300,126886$. [CrossRef]

73. Mehrjerdi, Y.Z.; Shafiee, M. A resilient and sustainable closed-loop supply chain using multiple sourcing and information sharing strategies. J. Clean. Prod. 2020, 289, 125141. [CrossRef]

74. Jouzdani, J.; Govindan, K. On the sustainable perishable food supply chain network design: A dairy products case to achieve sustainable development goals. J. Clean. Prod. 2020, 278, 123060. [CrossRef]

75. Karki, S.T.; Bennett, A.C.T.; Mishra, J.L. Reducing food waste and food insecurity in the UK: The architecture of surplus food distribution supply chain in addressing the sustainable development goals (Goal 2 and Goal 12.3) at a city level. Ind. Mark. Manag. 2021, 93, 563-577. [CrossRef]

76. Mavi, R.K.; Mavi, N.K. National eco-innovation analysis with big data: A common-weights model for dynamic DEA. Technol. Forecast. Soc. Chang. 2020, 162, 120369. [CrossRef]

77. Karaosman, H.; Perry, P.; Brun, A.; Morales-Alonso, G. Behind the runway: Extending sustainability in luxury fashion supply chains. J. Bus. Res. 2018, 117, 652-663. [CrossRef]

78. Cai, Y.J.; Choi, T.M. A United Nations' Sustainable Development Goals perspective for sustainable textile and apparel supply chain management. Transp. Res. Part E Logist. Transp. Rev. 2020, 141, 102010. [CrossRef]

79. Cozzio, C.; Volgger, M.; Taplin, R.; Woodside, A.G. Nurturing tourists' ethical food consumption: Testing the persuasive strengths of alternative messages in a natural hotel setting. J. Bus. Res. 2020, 117, 268-279. [CrossRef]

80. Dauvergne, P. Is artificial intelligence greening global supply chains? Exposing the political economy of environmental costs. Rev. Int. Political Econ. 2020, 1-23. [CrossRef]

81. Chicco, A.; Diana, M. Air emissions impacts of modal diversion patterns induced by one-way car sharing: A case study from the city of Turin. Transp. Res. Part D Transp. Environ. 2021, 91, 102685. [CrossRef]

82. de Villiers, C.; Kuruppu, S.; Dissanayake, D. A (new) role for business-Promoting the United Nations' Sustainable Development Goals through the internet-of-things and blockchain technology. J. Bus. Res. 2020, 131, 598-609. [CrossRef]

83. Varriale, V.; Cammarano, A.; Michelino, F.; Caputo, M. Sustainable supply chains with blockchain, IoT and RFID: A simulation on order management. Sustainability 2021, 13, 6372. [CrossRef]

84. Meqdadi, O.; Johnsen, T.E.; Johnsen, R.E.; Salmi, A. Monitoring and mentoring strategies for diffusing sustainability in supply networks. Supply Chain Manag. Int. J. 2020, 25, 729-746. [CrossRef]

85. Figge, F.; Thorpe, A.S.; Good, J. Us before me: A group level approach to the circular economy. Ecol. Econ. 2020, $179,106838$. [CrossRef]

86. Shashi, S.; Centobelli, P.; Cerchione, R.; Ertz, M. Food cold chain management: What we know and what we deserve. Supply Chain. Manag. 2021, 26, 102-135. [CrossRef]

87. Mani, V.; Jabbour, C.J.C.; Mani, K.T.N. Supply chain social sustainability in small and medium manufacturing enterprises and firms' performance: Empirical evidence from an emerging Asian economy. Int. J. Prod. Econ. 2020, 227, 107656. [CrossRef]

88. Guo, S.; Sun, X.; Lam, H.K.S. Applications of Blockchain Technology in Sustainable Fashion Supply Chains: Operational Transparency and Environmental Efforts. IEEE Trans. Eng. Manag. 2020, 1-17. [CrossRef]

89. Varriale, V.; Cammarano, A.; Michelino, F.; Caputo, M. The unknown potential of blockchain for sustainable supply chains. Sustainability 2020, 12, 9400. [CrossRef]

90. Mohammed, A. Towards a sustainable assessment of suppliers: An integrated fuzzy TOPSIS-possibilistic multi-objective approach. Ann. Oper. Res. 2019, 293, 639-668. [CrossRef]

91. Sabatini, A.; O'Toole, T.; Gregori, G. Integrating sustainability in business network initiation: The case of an Italian pasta maker. J. Bus. Ind. Mark. 2021, 36, 1894-1908. [CrossRef]

92. Sovacool, B.K.; Bazilian, M.; Griffiths, S.; Kim, J.; Foley, A.; Rooney, D. Decarbonizing the food and beverages industry: A critical and systematic review of developments, sociotechnical systems and policy options. Renew. Sustain. Energy Rev. 2021, 143, 110856. [CrossRef]

93. Venkatesh, V.G.; Zhang, A.; Deakins, E.; Mani, V. Drivers of sub-supplier social sustainability compliance: An emerging economy perspective. Supply Chain Manag. Int. J. 2020, 25, 655-677. [CrossRef]

94. Mohammadi, E.; Singh, S.J.; Habib, K. Electronic waste in the Caribbean: An impending environmental disaster or an opportunity for a circular economy? Resour. Conserv. Recycl. 2020, 164, 105106. [CrossRef]

95. Osti, L.; Goffi, G. Lifestyle of health \& sustainability: The hospitality sector's response to a new market segment. J. Hosp. Tour. Manag. 2021, 46, 360-363. [CrossRef]

96. Lin, Y.T.; Sun, H.; Wang, S. Designing sustainable products under coproduction technology. Manuf. Serv. Oper. Manag. 2020, 22, 1181-1198. [CrossRef]

97. Saha, K.; Dey, P.K.; Papagiannaki, E. Implementing circular economy in the textile and clothing industry. Bus. Strat. Environ. 2021, 30, 1497-1530. [CrossRef]

98. Calabrese, A.; Costa, R.; Ghiron, N.L.; Menichini, T.; Miscoli, V.; Tiburzi, L. Operating modes and cost burdens for the European deposit-refund systems: A systematic approach for their analysis and design. J. Clean. Prod. 2020, 288, 125600. [CrossRef] 
99. Shoukohyar, S.; Seddigh, M.R. Uncovering the dark and bright sides of implementing collaborative forecasting throughout sustainable supply chains: An exploratory approach. Technol. Forecast. Soc. Chang. 2020, 158, 120059. [CrossRef]

100. Ortiz-Barrios, M.; Cabarcas-Reyes, J.; Ishizaka, A.; Barbati, M.; Jaramillo-Rueda, N.; Carrascal-Zambrano, G.d. A hybrid fuzzy multi-criteria decision making model for selecting a sustainable supplier of forklift filters: A case study from the mining industry. Ann. Oper. Res. 2020, 307, 443-481. [CrossRef]

101. Centobelli, P.; Cerchione, R.; Esposito, E. Pursuing supply chain sustainable development goals through the adoption of green practices and enabling technologies: A cross-country analysis of LSPs. Technol. Forecast. Soc. Chang. 2020, 153, 119920. [CrossRef]

102. Sheppard, P.; Rahimifard, S. Embodied energy in preventable food manufacturing waste in the United Kingdom. Resour. Conserv. Recycl. 2019, 146, 549-559. [CrossRef]

103. Han, J.W.; Zuo, M.; Zhu, W.Y.; Zuo, J.H.; Lü, E.L.; Yang, X.T. A comprehensive review of cold chain logistics for fresh agricultural products: Current status, challenges, and future trends. Trends Food Sci. Technol. 2021, 109, 536-551. [CrossRef]

104. Qi, H.; Zeng, S.; Shi, L.; Dong, X. What the reclaimed water use can change: From a perspective of inter-provincial virtual water network. J. Environ. Manag. 2021, 287, 112350. [CrossRef] [PubMed] 